Article

\title{
Granular Calcite Stimulates Natural Mycorrhization and Growth of White Spruce Seedlings in Peat-Based Substrates in Forest Nursery
}

\author{
Mohammed S. Lamhamedi ${ }^{1,2, *}$, Mario Renaud ${ }^{1}$, Isabelle Auger ${ }^{1}$ and J. André Fortin ${ }^{2}$ \\ 1 Direction de la Recherche Forestière, 2700, rue Einstein, Québec, QC G1P 3W8, Canada; \\ mariorenaud@hotmail.com (M.R.); isabelle.auger@mffp.gouv.qc.ca (I.A.) \\ 2 Centre d'étude de la Forêt, Faculté de Foresterie, de Géographie et de Géomatique, Université Laval, \\ Pavillon Abitibi Price, Rue de la Terrasse, Québec, QC G1V 0A6, Canada; j.andre.fortin@videotron.ca \\ * Correspondence: mohammed.lamhamedi@mffp.gouv.qc.ca
}

Received: 29 June 2020; Accepted: 17 July 2020; Published: 21 July 2020

\begin{abstract}
The acidity of peat-based substrates used in forest nurseries limits seedling mineral nutrition and growth as well as the activity of microorganisms. To our knowledge, no study has yet evaluated the use of granular calcite as a covering material to increase $\mathrm{pH}$, calcium and $\mathrm{CO}_{2}$ concentrations in the rhizosphere and ectomycorrhizal development. The objective is to compare different covering treatments on early colonization of the roots by ectomycorrhizal fungi, as well as the growth and calcium nutrition of white spruce seedlings in the forest nursery. Three treatments were used to cover the plant cavities (Silica ( $29 \mathrm{~g} /$ cavity; control treatment), Calcite ( $24 \mathrm{~g} /$ cavity) and calcite+ ( $31 \mathrm{~g} / \mathrm{cavity})$ ) and were distributed randomly inside each of the five complete blocks of the experimental design. The results show that calcite stimulates natural mycorrhization. Seedlings grown with calcite have significant gains for several growth and physiological variables, and that the periphery of their root plugs are more colonized by the extramatrical phase of ectomycorrhizal fungi, thus improving root-plug cohesion. The authors discuss the operational scope of the results in relation to the tolerance of seedlings to environmental stress and the improvement of their quality, both in the nursery and in reforestation sites.
\end{abstract}

Keywords: ectomycorrhizal fungi; growth; mineral nutrition; peat-based substrate; physicochemistry; Picea glauca; forest nursery

\section{Introduction}

The production of boreal forest seedlings in peat-based substrates presents a significant challenge because of the acidity and variations in the physical properties of these substrates over a production cycle. These factors limit oxygen availability and affect the absorption kinetics of mineral nutrients, microorganism activity, along with shoot and root growth [1-4]. The container cavities in which the seedlings are produced are usually covered with silica. Due to their chemical composition, the granules or fine particles of silica $\left(\mathrm{SiO}_{2}\right)$ do not induce variations in the $\mathrm{pH}$ of the substrate. In order to increase the $\mathrm{pH}$ of acidic peat-based substrates, certain forest nurseries in Quebec (Canada) and elsewhere have used the addition of calcic $\left(\mathrm{CaCO}_{3}\right)$ or dolomite $\left(\mathrm{CaMg}\left(\mathrm{CO}_{3}\right)_{2}\right)$ lime powder to their substrates. Increasing the $\mathrm{pH}$ aims at improving the availability and absorption of mineral nutrients and seedling growth in forest nurseries $[1,3,5-7]$. However, the $\mathrm{pH}$ generated by lime addition is neither stable nor optimal for the mineral nutrition and growth of seedlings [8,9]. Rapid, uncontrolled $\mathrm{pH}$ increases of the peat-based substrate (up to values above 7) results in symptoms of mineral deficiency (e.g., iron, boron) and stunted coniferous and deciduous seedlings, which fail to meet morphophysiological quality standards $[3,5,8]$. 
Our previous work on the physical properties of peat-based substrates used for the production of white spruce (Picea glauca (Moench) Voss) seedlings in forest nurseries focused on optimizing texture, aeration, rhizosphere gas diffusion, fertility and water retention capacity [10,11]. Other work has led to the improvement of plant growth and root-plug cohesion for several forest species through the optimization of different growth techniques at the operational scale: container characteristics, water stress, short-day treatments [12,13], management of cumulative light intensity in relation to the optical characteristics of the tunnel and according to the growth stage [14], irrigation [15-17] and fertilization [18-20].

To further improve seedling growth and overall performance in nurseries and reforestation sites, special attention has been paid to the development of nursery seedling inoculation techniques using ectomycorrhizal spores and inoculum (liquid and solid) of selected strains or genotypes obtained by controlled cross-breeding between compatible monokaryons of ectomycorrhizal fungi [21-24]. The main challenges of nursery seedling inoculation were the optimization of substrate fertilization and physicochemical parameters, and the use of effective strains capable of rapidly colonizing roots and competing with natural strains. Laboratory work has previously been carried out to optimize $\mathrm{pH}$ for fungal growth in agar media in the absence [25] and presence of the host plant, in peat-based substrates, and in hydroponic systems [26-29]. However, to our knowledge, no studies have yet assessed the possibility of using granular calcite as covering material to improve rhizosphere chemistry. This calcite overlay aims at increasing $\mathrm{pH}, \mathrm{Ca}$ and $\mathrm{CO}_{2}$ concentrations in order to stimulate early root colonization by ectomycorrhizal fungi naturally present in the nursery, extension of their extramatrical phase, and growth of seedlings in forest nurseries. In reality, when fine calcite particles are exposed to water (irrigation, rain, etc.), they will dissociate according to the following chemical reaction (1):

$$
\mathrm{CaCO}_{3}+\mathrm{H}_{2} \mathrm{O} \rightarrow \mathrm{Ca}^{2+}+\mathrm{CO}_{2}+2(\mathrm{OH})^{-}
$$

To improve seedling morphophysiological quality and to reduce the costs associated with artificial ectomycorrhizal inoculation while promoting natural root ectomycorrhization, our approach is to replace silica, currently used as covering material, by granular calcite. Our hypothesis is that granular calcite improves substrate $\mathrm{pH}$, early root colonization by ectomycorrhizal fungi in response to increased concentrations of calcium and $\mathrm{CO}_{2}$ in the rhizosphere released by calcite, and seedling mineral nutrition and growth when compared to silica-based covering material. Unlike strains selected for artificial inoculation (which include only one or a few genotypes), naturally present ectomycorrhizal fungi are genetically diverse, adapted to different environmental stresses and compatible with forest species and the climatic conditions of the boreal forest [22,30].

In Quebec's forest nurseries, the growing season is very short. Seedlings are fertilized throughout the active growing season in order for them to reach the established morphophysiological quality standards (height, foliar nitrogen concentration, etc.). In this context, it is desirable to promote natural mycorrhization during the fall through ectomycorrhizal "spore showers" from forest stands located near these nurseries [22]. Improved morphophysiological quality and increased seedling ectomycorrhization will contribute to their survival and improve their tolerance to environmental stresses once they are planted at reforestation sites [23,31]. Indeed, with climate change in the boreal forest, transplanted forest seedlings will be subjected to more severe and frequent environmental stresses (drought, frost, pathogens, etc.).

Thus, the main objectives of this study are: (i) to compare the effects of granular calcite and silica on the main physicochemical characteristics of the substrate, on the early extension of the extramatrical phase of ectomycorrhizal fungi and on the growth and calcium nutrition of containerized white spruce seedlings during the second growing season $(2+0)$ in a nursery, and (ii) to compare logistic models of seedling growth based on covering material (silica, calcite) and the presence or absence of ectomycorrhizal colonization. 


\section{Materials and Methods}

\subsection{Plant Material, Covering Material and Experiment Design}

White spruce seeds (seedlot: EPB-V3-EST-2-0; production code GP35EPB14-P85) were sown in 25-10 containers (model IPL, Saint-Damien, QC, Canada; 25 cavities, $310 \mathrm{~cm}^{3} /$ cavity; 206 seedlings $/ \mathrm{m}^{2}$ ). The containers were placed in a tunnel on 7 May 2014. The cavities were filled with a mixture of peat-based substrate and vermiculite (80\%:20\%, v/v), and bulk density was adjusted to $0.10 \mathrm{~g} / \mathrm{cm}^{3}$. The $\mathrm{pH}_{\text {water }}$ of the initial substrate prior to seeding was 3.4. In the substrate, large fibers (retained on $2 \mathrm{~mm}$ sieves), large and medium fibers (greater than $0.850 \mathrm{~mm}$ ), short (retained on $0.075 \mathrm{~mm}$ sieves) and fine fibers (those not retained on $0.075 \mathrm{~mm}$ sieves) accounted for $24.5 \%, 43.3 \%, 55.4 \%$ and $1.3 \%$ of the growing medium, respectively.

After the seeding operation, the seeds were covered with one of three types of materials, corresponding to the treatments: Silica ( $29 \mathrm{~g} /$ cavity; control treatment), Calcite (24 g/cavity) and Calcite+ (31 g/cavity). The amount of silica used in this project corresponds to the amount currently used at the operational scale. Calcite quantities, on the other hand, were established based on the results of our previous work [32], taking into account cavity volume and the effect of calcite on substrate $\mathrm{pH}$. After potting and seeding, precise quantities of the covering material were placed over each container by an automatic spreader. The silica and calcite used were of high physicochemical quality and had no adverse effect on root and shoot growth.

All three treatments (silica, calcite and calcite+) were randomly distributed within each of the five complete blocks of the experimental design. Each treatment consisted of 27 containers (25-310cc) per block, for a total of 10,125 seedlings throughout the entire experimental design (excluding buffer zones). To eliminate border effects, buffer zones (27 containers/zone) were added between treatments and between blocks.

The containers were placed in one of the production tunnels of the Grandes-Piles governmental forest nursery (latitude: $46^{\circ} 43^{\prime} 54^{\prime \prime} \mathrm{N}$; longitude: $72^{\circ} 42^{\prime} 06^{\prime \prime} \mathrm{W}$ ). During the first growing season, the tunnel was covered with a $4 \mathrm{~mm}$-thick milk-white polyethylene, with an incident light diminishing factor of 50-55\% (Ginegar Plastic Products Ltd., multi-layer greenhouse cover film, type UVA/white $45 \%$ ). The cover was retractable on both sides of the tunnel to increase ventilation and control the air temperature inside. The cover was removed around 6 October 2014, so the plants were exposed to outdoor conditions during their first winter and second growing season.

Germination was evaluated three times per week (Monday, Wednesday and Friday) in 60 containers ( 4 containers $\times 5$ blocks $\times 3$ treatments) during the first 31 days after seeding. This assessment showed that the mean cavity occupancy rate for all 3 treatments was $99.33 \%$. Once germination was complete, the germinants were thinned to one per cavity. No germinant was transplanted to empty cavities.

\subsection{White Spruce Seedling Production Techniques}

The seedlings were produced using the standard nursery cultural techniques used in Quebec to produce white spruce seedlings in containers [23,31].

Irrigation and fertilization were carried out using a robot (Aquaboom model, Industrie Harnois, Saint-Thomas-de-Joliette, QC, Canada) to eliminate the effects of spatial variability in the substrate's water content [15]. The robot's coefficient of uniformity varied from $95 \%$ to $98 \%$. Substrate water content was adjusted for each seedling growth stage during the first season $(1+0)[16]$ and maintained between $40 \%$ and $45 \%(v / v)$ during the second season $(2+0)$ [15]. Substrate water content $(\%, v / v)$ was monitored by gravimetry prior to irrigation [13].

The fertilization regime was adjusted every two weeks during both seasons $(1+0$ and $2+0)$ using the PLANTEC software, according to the growth stages [19]. By the end of the first growing season, each plant received $47.3 \mathrm{mg}$ of nitrogen $\left(\mathrm{N}: 25.0 \mathrm{mg} \mathrm{N}-\mathrm{NH}_{4}, 22.3 \mathrm{mg} \mathrm{N}-\mathrm{NO}_{3}\right), 10.6 \mathrm{mg}$ of phosphorus $(\mathrm{P})$, $15.2 \mathrm{mg}$ of potassium $(\mathrm{K})$ and $0.1 \mathrm{mg}$ of magnesium $(\mathrm{Mg})$, as well as micronutrients (manganese, copper, iron and boron). During the second growing season (30 April 2015, to 9 October 2015), each plant 
received $250.3 \mathrm{mg}$ of $\mathrm{N}\left(99.4 \mathrm{mg} \mathrm{N}-\mathrm{NH}_{4}, 111.8 \mathrm{mg} \mathrm{N}-\mathrm{NO}_{3}, 39.1 \mathrm{mg} \mathrm{N}-U r e a\right), 41 \mathrm{mg}$ of $\mathrm{P}, 83 \mathrm{mg}$ of $\mathrm{K}$ and $0.6 \mathrm{mg}$ of $\mathrm{Mg}$, in addition to trace elements. To prevent the seedlings from reaching undesirable height, as required per morphophysiological quality standards, $2+0$ seedlings were not fertilized between 25 June and 13 August 2015.

\subsection{Silica and Calcite Particle Size}

To characterize the statistical distribution of grain size, an analysis of silica and calcite particle size was performed by sieving [33]. Silica and calcite were sampled in the nursery prior to potting from the bulk piles of each type of covering material. To do so, three $500 \mathrm{~g}$ composite samples were used for each type of covering material (silica or calcite).

\subsection{Substrate Physicochemistry and Seedling Calcium Nutrition and Growth}

During the second growing season $(2+0)$, the physicochemical variables associated with substrate fertility and seedling morphophysiological variables (growth, mineral nutrition) were determined by seven destructive samplings conducted every three weeks from 25 May to 28 September 2015. Mineral nutrient analyses of seedlings and substrate were conducted at the Laboratoire de chimie organique et inorganique (organic and inorganic chemistry laboratory) of the Direction de la recherche forestière (Quebec forest research branch), using the methods described in Lamhammedi et al. 2013, among others $[18,34]$.

During each sampling, one container per treatment was randomly selected from each experimental block. In each of these containers, 15 of the 25 seedlings were randomly selected, for a total of 225 seedlings per sampling date (or 75 seedlings/treatment). The position of the container and the 15 sampled cavities were randomly selected. The same container and cavity positions were used for all block-treatment combinations at a given date.

Physicochemical characteristics and substrate fertility were assessed on one composite sample made of the 15 substrate root plugs per block and per treatment (root plugs were harvested along with the seedlings sampled for growth and mineral nutrition measurements). Substrate physicochemical variables include $\mathrm{pH}_{\text {water, }} \mathrm{pH}_{\mathrm{CaCl}_{2}}$, electrical conductivity, and the mineral concentration and content of mineral nitrogen, phosphorus, potassium, calcium, and magnesium. In addition to $\mathrm{pH}_{\mathrm{water}}$ which is commonly used by forest nurseries, $\mathrm{pH}_{\mathrm{CaCl}_{2}}$ was also measured to better characterize and approximate the real variations taking place in the physicochemistry of the mycorrhizosphere after calcite hydrolysis [34].

Several morphophysiological variables were measured on the sampled seedlings: shoot height and diameter (15 seedlings/block/treatment), shoot and root dry masses (3 composite samples of 5 seedlings/block/treatment), and mineral nutrition of seedlings (1 composite sample of 15 seedlings/block/treatment). The root system was first cleaned by a system with a jet of compressed air. The roots were then washed to remove any particles of peat. Roots were placed in paper pouches before drying and mineral nutrient analysis.

Root and shoot calcium concentrations were analyzed using a plasma atomic emission spectrometer (model: ICAP 9000, Thermo Instruments, Franklin, MA, USA). Calcium content was calculated by multiplying the concentration by the dry mass to reflect the amount of calcium contained in a given amount of plant material [35].

\subsection{Superficial Ectomycorrhizal Colonization of Seedling Root Plugs}

Natural mycorrhization of seedling roots was assessed once at the end of the second growing season. In Quebec, white spruce is produced under a tunnel during the first growing season and transferred outdoors for the second year. The tunnel acts as a barrier to spore showers and that is why ectomycorrhizal colonization is almost non-existent at stage $1+0$. At the end of the second growing season (27 October 2014) of the first growing season under tunnel conditions, we examined root tips of 
225 white spruce seedlings (75 seedlings/treatment, 15 seedlings/treatment1/block) and no mycorrhiza formation was observed.

At the end of the second growing season $(2+0)$, we visually assessed the percentage of superficial growth of the ectomycorrhizal fungi's extraradical mycelium (extramatrical phase) on the outside of each root plug. To do this, we randomly sampled 20 seedlings per container for each treatment in each block, for a total of 300 seedlings.

\subsection{Statistical Analysis and Modeling of Growth Variables}

\subsubsection{Analysis of Variance}

To assess the effects of the cover treatment and the sampling date on substrate fertility variables and seedling morphophysiological variables (growth, mineral nutrition, etc.) measured during the second growing season, variance analyses were performed using mixed linear models with the MIXED procedure of SAS/STAT version 14.1 (SAS Institute Inc. 2015. Cary, NC, USA) using the average of samples per block/treatment. Treatment, sampling date, and their interaction were considered fixed effects, while the block and the interaction between the block and treatment was considered to be random. A model with a fixed effect (treatment) and a random block effect was used to analyze the percentage of ectomycorrhizal colonization. In all models, the number of degrees of freedom of the denominator for the fixed effects tests was calculated using the Satterthwaite method. The number of degrees of freedom at the denominator is therefore specific to each variable analyzed.

When the fixed effect was significant at the $5 \%$ threshold, orthogonal contrasts were performed. The treatment effect was broken down into two contrasts: mean calcite/calcite+ vs. Silica, on the one hand, and calcite vs. calcite+, on the other hand. If the interaction between date and treatment was significant, treatment contrasts were performed for each date. The effect of time was broken down into two contrasts: linear and quadratic. When the interaction between treatment and date was significant, the temporal evolution was compared between the treatments using these two contrasts. Thus, the linear effect and the quadratic effect of time were compared for calcite/calcite+ vs. silica treatments, and for calcite vs. calcite+ treatments. The contrasts tests were based on a simulation method with the ADJUST = SIMULATE option in SAS/STAT (version 14.1).

The hypotheses of variance normality and homogeneity were checked graphically. Where necessary, a residual variance by date was estimated to take into account variance heterogeneity. Preliminary analyses showed that sampling dates were not associated to a temporal correlation between the data.

Pearson correlation coefficients were calculated between the substrate's different physicochemical variables.

\subsubsection{Modeling of Growth Variables}

The temporal evolution of each of the growth variables $(y)$ was modeled with the logistic function (2) using a mixed nonlinear model and the NLMIXED procedure of SAS/STAT version 14.1 (SAS Institute Inc.):

$$
y=\frac{a+u}{1+e^{-c(d a y-b)}}
$$

where parameters $a, b$, and $c$ are, respectively, the asymptote, inflection point and growth rate. Parameter $u$ is the random effect of the interaction between the block and the treatment.

To test for differences in the kinetics of the assessed growth variables between the three treatments during the growing season, indicator variables were added to the model (3). These variables are defined as $i_{1}=1$ if (treatment $=$ calcite, otherwise, $i_{1}=0$, and $i_{2}=1$ if treatment $=$ calcite + , otherwise, $i_{2}=0$.

$$
y=\frac{a_{0}+a_{1} i_{1}+a_{2} i_{2}+u}{1+e^{-\left(c_{0}+c_{1} i_{1}+c_{2} i_{2}\right)\left(\text { day }-\left(b_{0}+b_{1} i_{1}+b_{2} i_{2}\right)\right)}}
$$


when there was no significant difference between calcite and calcite + for a given parameter, only one parameter common to both treatments was used $\left(a_{12}, b_{12}, c_{12}\right)$. The model was then simplified by removing the indicator variables that were not significant at the $5 \%$ threshold. Models were adjusted to the dataset for the different sampling dates.

Residue normality and homogeneity of variance hypotheses were checked graphically. To account for the heterogeneity of the variances, the residual variance was weighted according to the variance observed at each date. Logistic model adjustment was checked graphically by comparing the predicted values with the averages observed at each time per treatment. A coefficient of determination $\left(R^{2}\right)(4)$ was calculated as follows:

$$
\mathrm{R}^{2}=1-\left[\sum(y-\hat{y})^{2} / \sum(y-\bar{y})^{2}\right]
$$

where $\hat{y}$ is the value predicted by the model and is $\bar{y}$ the mean of $y$.

\section{Results}

\subsection{Silica and Granular Calcite Particle Size}

The particle size analysis shows that silica and calcite differ in their particle size proportions (Figure 1), and that these two materials do not have the same distribution according to the four observed particle size classes (very fine: $0.425 \mathrm{~mm}$; medium: $>1.00 \mathrm{~mm}$; coarse: $>2.00 \mathrm{~mm}$ ). Calcite contains a much larger proportion of very fine and fine particles $(16.7 \%)$, and medium particles $(58.6 \%)$ than silica (1.1\% and $20.5 \%$; Figure 1$)$, while silica contains much more coarse particles $(78.3 \%)$ than calcite $(24.7 \%)$.

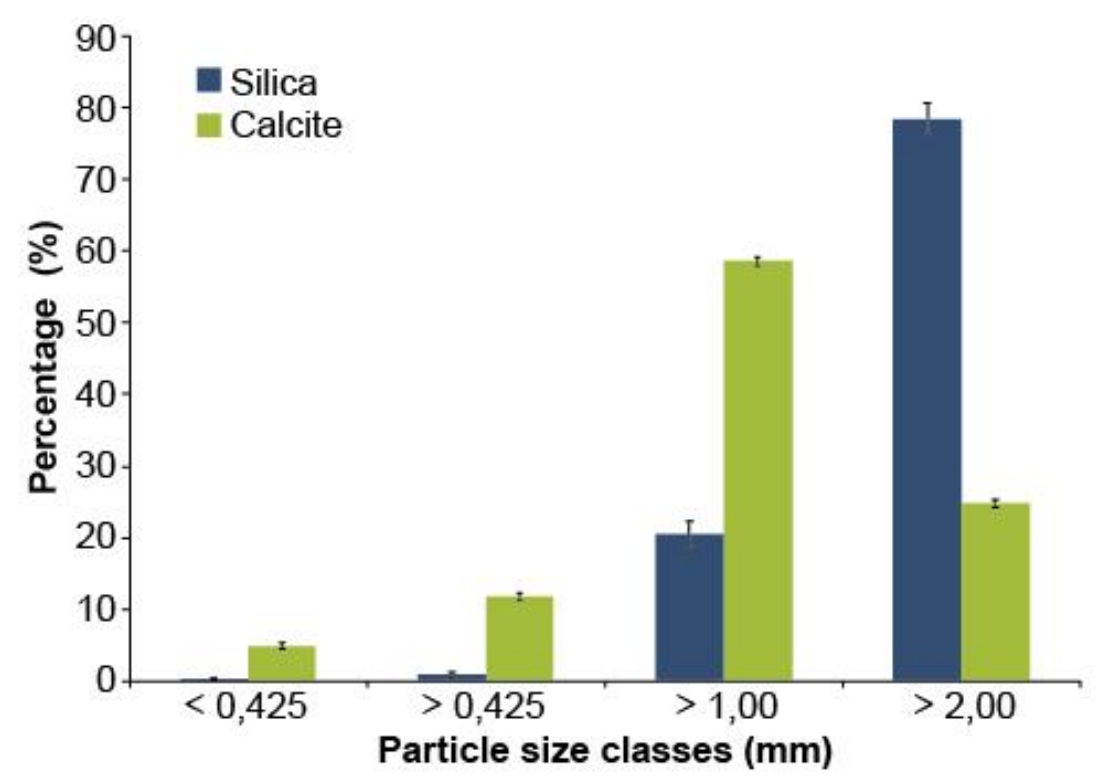

Figure 1. Particle size distribution of silica and calcite used as covering material during the production of white spruce seedlings ( $n=3$ composite samples of each covering material. The error bars represent the standard error).

\subsection{Physicochemical Properties and Fertility of the Substrate}

The effects of the Date $\times$ Treatment interaction, the date (linear and quadratic effects), and the treatment were significant for most substrate physicochemical and fertility variables $\left(\mathrm{pH}_{\mathrm{water}}, \mathrm{pH}_{\mathrm{CaCl}_{2}}\right.$, $\mathrm{N}_{\min }, \mathrm{P}, \mathrm{K}, \mathrm{Ca}$, and $\mathrm{Mg}$ ) measured during the second growing season (2+0) (Table 1). In all cases, no significant difference was observed between the two calcite treatments (calcite vs. calcite+: $p \geq 0.5398$ ). Except for conductivity, the mean of the two calcite treatments (calcite/calcite+) was significantly different from that of the silica treatment for all assessed substrate physicochemical and fertility variables. 
Orthogonal contrasts show that mean substrate $\mathrm{pH}$ was significantly higher in calcite and calcite+ treatments than silica during the second growing season for both $\mathrm{pH}_{\mathrm{CaCl}_{2}}$ (Table 1, Figure 2) and $\mathrm{pH}_{\text {water }}$ (Table 1). At the end of the second growing season (28 September 2015), both $\mathrm{pH}$ values were higher in calcite/calcite+ treatments $\left(\mathrm{pH}_{\text {water }}=4.9\right.$ and $\left.\mathrm{pH}_{\mathrm{CaCl}_{2}}=3.8\right)$ than in silica treatments $\left(\mathrm{pH}_{\text {water }}=4.4\right.$ and $\left.\mathrm{pH}_{\mathrm{CaCl}_{2}}=3.4\right)$.

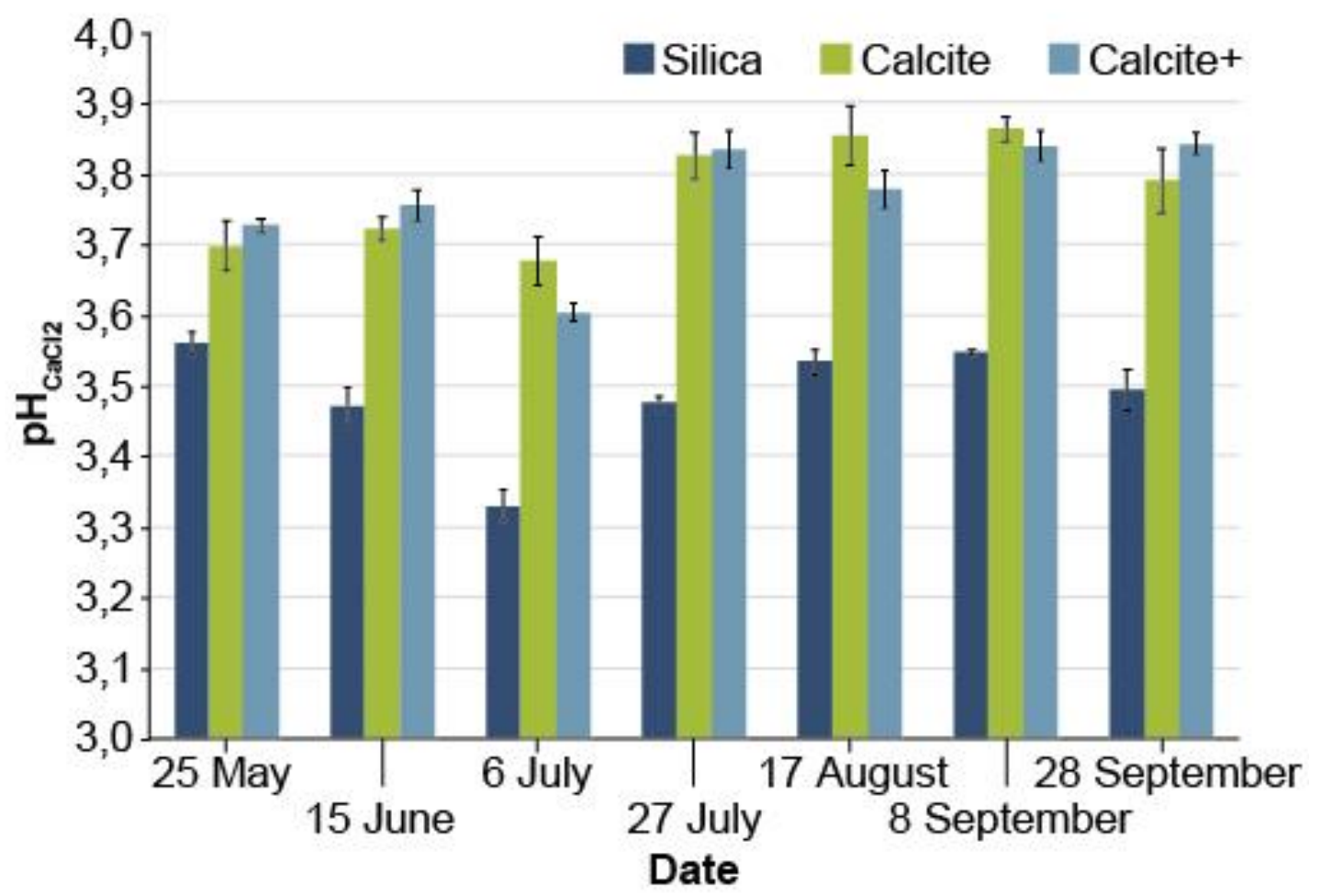

Figure 2. Evolution of $\mathrm{pH}_{\mathrm{CaCl}_{2}}$ of peat growth substrate during the growing season of white spruce seedlings (2+0), depending on the covering material (silica: $29 \mathrm{~g} /$ cavity, calcite: $24 \mathrm{~g} /$ cavity and calcite+: $31 \mathrm{~g} /$ cavity).

The Ca concentration was significantly higher in calcite-covered substrates than in silica-covered substrates for all sampling dates. For example, at the last sampling date, the substrate's Ca concentration was significantly greater in calcite/calcite+ treatments $(125.5 \pm 10 \mathrm{ppm})$ than in silica treatments $(43 \pm 13 \mathrm{ppm})$. Substrate $\mathrm{pH}$ and Ca concentrations were significantly correlated $\left(\mathrm{pH}_{\text {eau }}: \mathrm{r}=-0.60\right.$, $\left.\mathrm{pH}_{\mathrm{CaCl}_{2}}: \mathrm{r}=0.30, p=0.002\right)$.

\subsection{Superficial Ectomycorrhizal Colonization of Seedling Root Plugs}

At the end of the second growing season, the percentage of superficial colonization of white spruce seedling root plugs by the extraradical mycelium (e.g., extramatrical phase) of the ectomycorrhizal fungus significantly varied with the covering material $(p<0.0001)$. Orthogonal contrasts showed that the mean degree of root plug surface colonization by ectomycorrhizal fungi was significantly greater $(p<0.0001)$ in calcite/calcite+ treatments $(61 \%)$ than in silica treatments ( $8 \%)$ (Figure 3a,b). However, the difference was not significant $(p=0.1045)$ between calcite $(54 \%)$ and calcite+ $(68 \%)$ treatments. Colonization by the extramatrical phase of ectomycorrhizae showed the same pattern on all root plugs examined, i.e., from the top (covering material) to bottom (Figure 3b). 


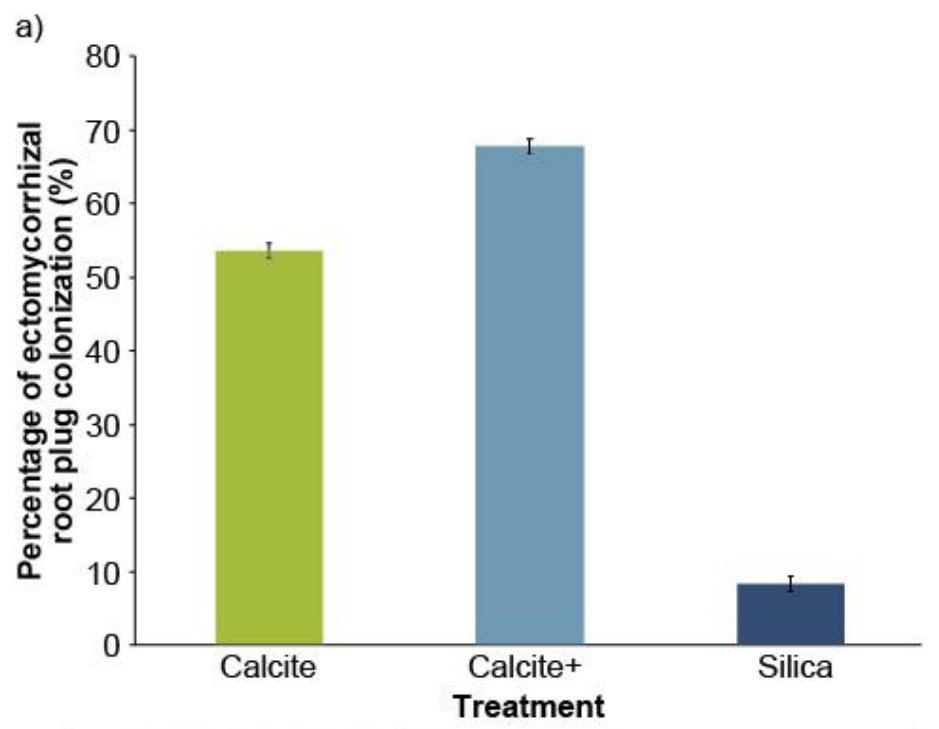

b)

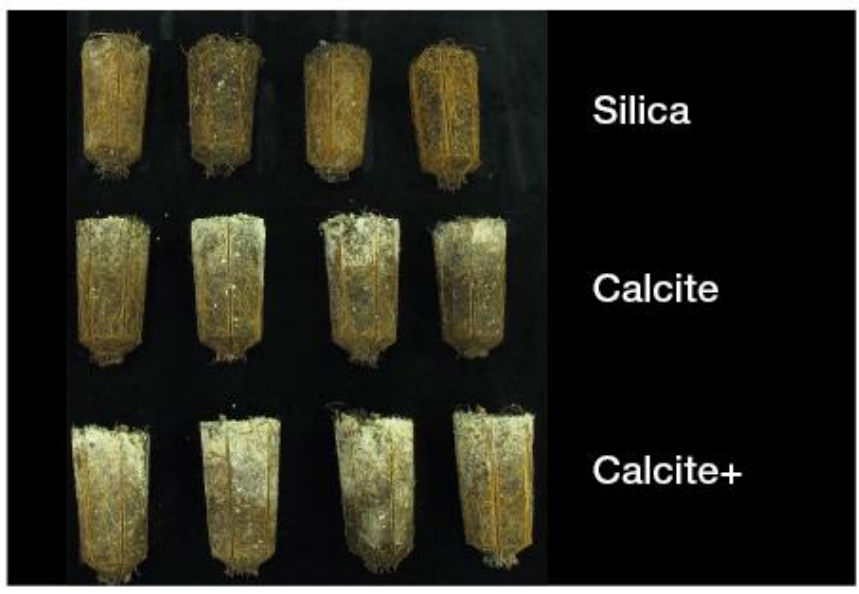

Figure 3. (a) Percentage of superficial colonization of the root system of white spruce $(2+0)$ seedlings ( $n=100$ seedlings/treatment) by the extramatrical phase of the ectomycorrhizal fungi Laccaria bicolor in autumn (28 September, 2015); (b) example of variability in the surface colonization of root plugs of white spruce seedlings $(2+0)$ by L. bicolor depending to the covering material (Silica: $29 \mathrm{~g} / \mathrm{cavity}$, Calcite: $24 \mathrm{~g} /$ cavity and Calcite $+: 31 \mathrm{~g} /$ cavity, volume of each cavity $=310 \mathrm{~cm}^{3}$ ).

The majority of seedlings were colonized by Laccaria bicolor (Maire) P.D.Orton, the most abundant ectomycorrhizal fungus in Quebec forest nurseries. The dichotomous structures of ectomycorrhizae, of $L$. bicolor are easily visible to the naked eye on the surface of the root plugs of white spruce seedlings. On a microscopic scale, these structures are characterized by the presence of mantle hyphae and Hartig net hyphae. Fruiting bodies of this fungus are very abundant in association with several forest species (white spruce, black spruce (Picea mariana [Mill.] B.S.P.), jack pine (Pinus banksiana Lamb.), white pine (Pinus strobus L.), etc.). L. bicolor can easily be identified by its rubber smell, lilac-colored base, white spore-print, and subglobose to ellipsoid echinulate spores (Rolland Labbé, Mycoquébec). Of the 300 sampled seedlings, only one had been superficially colonized by Telephora terrestris Ehrhenberg Pl. Crypt. Linn. Exsicc. on a small portion $(<25 \%)$ of the root plug area.

\subsection{White Spruce Seedlings Growth during the Second Growing Season (2+0)}

The Date $\times$ Treatment interaction was significant $(p \leq 0.0433)$ for all growth variables except root diameter and dry mass (Table 2). Simple effects of treatment and date were significant $(p \leq 0.0005)$ for all growth variables. 
Table 1. Observed probabilities ( $p$-values) and degrees of freedom of the fixed effects associated with the analysis of the variance of the fertility and physicochemical variables of the substrate during the second $(2+0)$ growing season of white spruce seedlings in a forest nursery. A $p$-value in bold indicates a significant Date $\times$ Treatment interaction at $p<0.05$.

\begin{tabular}{|c|c|c|c|c|c|c|c|c|c|c|}
\hline \multirow{2}{*}{ Source of Variation. } & \multicolumn{2}{|c|}{ Degrees of Freedom * } & \multicolumn{8}{|c|}{$p$ Values } \\
\hline & DLN & DLD & $\mathrm{pH}_{\text {water }}$ & $\mathrm{pH}_{\mathrm{CaCl}_{2}}$ & Cond $^{+}(\mu \mathrm{S} / \mathrm{cm})$ & $\mathrm{N}_{\min }{ }^{+}(\mathrm{mg} / \mathrm{kg})$ & $\mathrm{P}^{+}(\mathrm{mg} / \mathrm{kg})$ & $\mathrm{K}^{+}(\mathrm{mg} / \mathrm{kg})$ & $\mathrm{Ca}^{+}$(mg/kg) & $\mathrm{Mg}^{+}(\mathrm{mg} / \mathrm{kg})$ \\
\hline Treatment & 2 & 8 & $<0.0001$ & 0.0051 & 0.2459 & 0.0029 & $<0.0001$ & 0.0012 & $<0.0001$ & 0.0003 \\
\hline Calcite/calcite+ vs. silica & (1) & 8 & $<0.0001$ & 0.0017 & 0.0990 & 0.0008 & $<0.0001$ & 0.0003 & $<0.0001$ & 0.0001 \\
\hline Calcite vs. calcite+ & (1) & 8 & 0.6844 & 0.5398 & 0.9562 & 0.5734 & 0.9970 & 0.7603 & 0.5976 & 0.7471 \\
\hline Date & 6 & 70 & $<0.0001$ & $<0.0001$ & $<0.0001$ & $<0.0001$ & $<0.0001$ & $<0.0001$ & $<0.0001$ & $<0.0001$ \\
\hline Date (linear effect) & (1) & 70 & $<0.0001$ & $<0.0001$ & $<0.0001$ & $<0.0001$ & $<0.0001$ & $<0.0001$ & $<0.0001$ & $<0.0001$ \\
\hline Date (quadratic effect) & (1) & 70 & 0.0213 & $<0.0001$ & $<0.0001$ & $<0.0001$ & $<0.0001$ & $<0.0001$ & $<0.0001$ & $<0.0001$ \\
\hline Date $\times$ Treatment & 12 & 70 & $<0.0001$ & 0.0001 & $<0.0001$ & 0.0001 & $<0.0001$ & $<0.0001$ & $<0.0001$ & $<0.0001$ \\
\hline
\end{tabular}

${ }^{*}$ DLN: degrees of freedom of the numerator and DLD: degrees of freedom of the denominator according to Satterthwaite's correction. The DLDs presented are those for pHeau and

$\mathrm{pHCaCl}_{2}$. They vary from 13 to 30 for the other variables. ${ }^{+}$Cond.: electrical conductivity, $\mathrm{N}_{\min }$ : mineral nitrogen, $\mathrm{P}$ : phosphorus, $\mathrm{K}$ : potassium, Ca: calcium and $\mathrm{Mg}$ : magnesium.

Table 2. Observed probabilities ( $p$-values) and degrees of freedom of the fixed effects associated with the analysis of the variance of the growth variables of white spruce $(2+0)$ seedlings under forest nursery conditions. A value of $\mathrm{p}$ in bold indicates a significant effect at $p<0.05$ of the Date $\times$ Treatment interaction, a Treatment effect or a Date effect.

\begin{tabular}{|c|c|c|c|c|c|c|c|c|}
\hline \multirow{3}{*}{ Source of Variation } & \multicolumn{2}{|c|}{ Degrees of Freedom * } & \multicolumn{6}{|c|}{$p$ Values } \\
\hline & \multirow{2}{*}{ DLN * } & \multirow{2}{*}{ DLD * } & \multirow{2}{*}{ Height $(\mathrm{H}, \mathrm{cm})$} & \multirow{2}{*}{ Diameter $(\mathrm{D}, \mathrm{mm})$} & \multirow{2}{*}{ H/D } & \multicolumn{3}{|c|}{ Dry Mass } \\
\hline & & & & & & Shoots (mg) & Roots (mg) & Total (mg \\
\hline Calcite/calcite+ vs. silica & $(1)$ & 12 & $<0.0001$ & 0.0001 & $<0.0001$ & $<0.0001$ & 0.0007 & $<0.0001$ \\
\hline Calcite vs. calcite+ & (1) & 12 & 0.6702 & 0.2906 & 0.3109 & 0.0408 & 0.0293 & 0.0310 \\
\hline Date & 6 & 70 & $<0.0001$ & $<0.0001$ & $<0.0001$ & $<0.0001$ & $<0.0001$ & $<0.0001$ \\
\hline Date (linear effect) & $(1)$ & 71 & $<0.0001$ & $<0.0001$ & $<0.0001$ & $<0.0001$ & $<0.0001$ & $<0.0001$ \\
\hline Date $\times$ Treatment & 12 & 70 & $<0.0001$ & 0.0527 & 0.0433 & 0.0003 & 0.2998 & 0.0008 \\
\hline
\end{tabular}

* DLN: degrees of freedom of the numerator and DLD: degrees of freedom of the denominator. The DLDs presented are those for height and diameter. They vary from 18 to 26 for shoot dry mass, 20 to 48 for root dry mass and 19 to 26 for total dry mass. 
The mean diameter of the seedlings that received the calcite treatment was not significantly different from that of the seedlings who received the calcite+ treatment $(p=0.2906)$. However, the combined mean diameter of the seedlings who received calcite and calcite treatments was significantly greater than that of the silica treatment ( $p=0.0001$; Table 2). Mean root dry mass differed significantly between calcite and calcite+ treatments $(p=0.0293)$ and between calcite/calcite + and silica treatments $(p=0.0007)$.

The differences between calcite and calcite+ treatments were not significant at any of the sampling dates for the other four growth variables (height $(\mathrm{H})$, height to diameter ratio (H/D), shoot mass, and total dry mass). At most of these dates, the average of calcite/calcite+ treatments was nonetheless significantly higher than that of silica treatments.

At the end of the second growing season, seedlings treated with calcite and calcite+ showed significant increases in height $(21.7 \%$ on average), diameter (9.1\% on average), shoot dry mass $(20.6 \%)$, and total dry mass (18.3\%) compared to silica treatments (Figure 4 ).
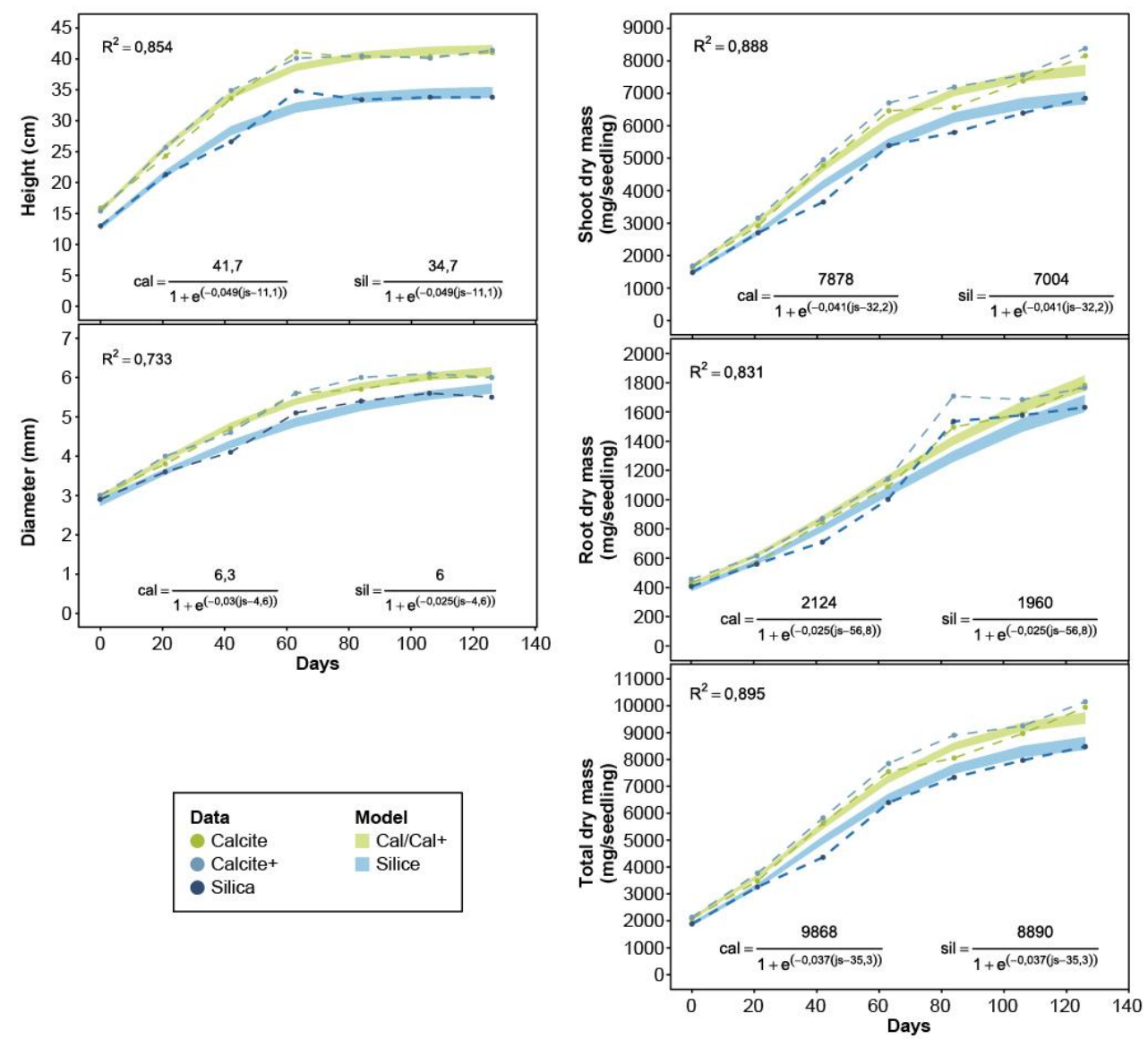

Figure 4. Evolution of the means and logistic models adjusted for each of the growth variables of white spruce seedlings $(2+0)$, depending on the treatments (silica, calcite and calcite + ). The width of each band corresponds to the $95 \%$ confidence interval. As the parameters of the calcite and calcite treatments did not differ significantly from each other, a single logistic model was generated by combining the data from these two treatments. The models were adjusted using all the data $(n=525$ seedlings/treatment for height and diameter, and $n=105$ composite samples of 5 plants/treatment for shoot, roots and total dry masses).

\subsection{Logistic Growth Models}

Kinetics of the different growth variables are well adjusted to the logistic models ( $\mathrm{R}^{2}$ ranging from 0.733 to 0.895 , Figure 4). Many of these model parameters significantly differ between the silica treatment and the two calcite treatments (calcite/calcite+) (Figure 4, Table S1), but those of the calcite and 
calcite+ treatment models do not differ significantly from one another. This shows that white spruce $(2+0)$ seedlings that had their cavities covered with calcite have significant height, diameter, and dry mass gains (for the shoot and root, and for the whole plant) (Figure 4). For example, the asymptote of mean seedling height at the end of the second growing season was $41.7 \mathrm{~cm}$ in calcite/calcite+ treatments, but only $34.7 \mathrm{~cm}$ in the silica treatment.

\subsection{Seedling Calcium Nutrition}

The Date $\times$ Treatment interaction was significant for the calcium content $(p<0.0001)$, but not for the calcium concentration $(p=0.0742)$ in shoots. This interaction was also significant for root calcium content $(p<0.0001)$ and concentration $(p=0.0124)$. Simple effects of treatment and sampling date were significant for calcium content and concentration in the shoot and roots.

Orthogonal contrasts of the shoot calcium content showed no significant difference between calcite and calcite+ treatments regardless of the sampling date $(p>0.0530)$. Even so, the mean shoot calcium content was significantly higher $(p<0.0001)$ in the combined calcite/calcite+ treatments than in the silica treatment. The difference was significant at all sampling dates and it even increased during the growing season (Figure 5).

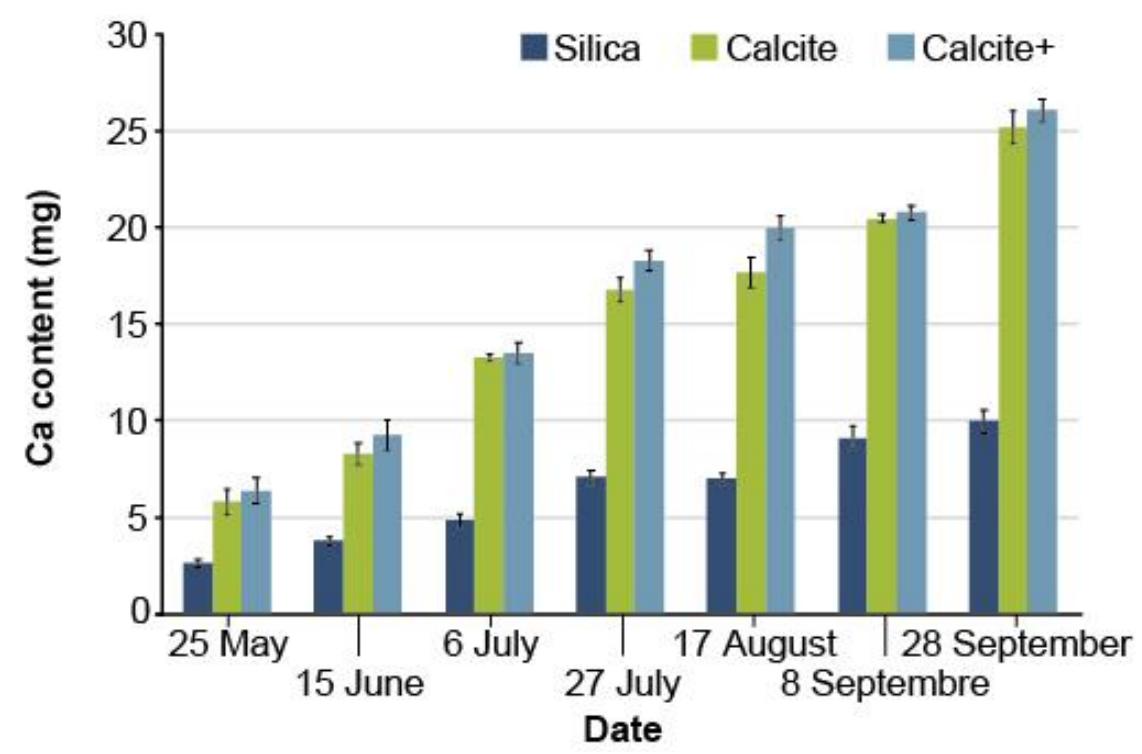

Figure 5. Evolution of the average mineral content of the shoots of white spruce seedlings $(2+0)$ in calcium (Ca), depending on the treatments (silica, calcite and calcite +$)(n=5$ composite samples of 15 plants each. The error bars represent the standard error).

With respect to the calcium concentration and content in the roots, the significant superiority of calcite/calcite+ treatments over the silica treatment persisted throughout the growing season, and at the last sampling date, the concentration (calcite/calcite+: $0.36 \pm 0.01 \%$; silica: $0.21 \pm 0.01 \%$ ) and Ca content (calcite/calcite+: $6.34 \pm 0.20 \mathrm{mg}$; silica: $3.46 \pm 0.26 \mathrm{mg}$ ) for the calcite/calcite+ treatments were almost double those of silica.

\section{Discussion}

The use of calcite rather than silica as covering material significantly improved the chemical properties of the peat-based substrate ( $\mathrm{pH}$ and $\mathrm{Ca}$ concentration), calcium nutrition, and the different growth variables of white spruce seedlings $(2+0)$ when produced at an operational scale. The use of calcite as covering material also significantly increased mycorrhization and surface colonization of root plugs $(2+0)$ by extraradical mycelium of $L$. bicolor, which was not observed with silica. The development 
of extraradical mycelium helps improve root plug cohesion and decrease insufficient root development (Figure 3).

\subsection{Calcite: A Key Factor in Stimulating Mycorrhization and Growth of the Extramatrical Phase of Ectomycorrhizal Fungi}

Early ectomycorrhizal colonization and rapid extension of extraradical mycelium outside root plugs of calcite-covered white spruce seedlings (2+0) (Figure 3 ) are synergically stimulated by several factors, including improved substrate $\mathrm{pH}, \mathrm{Ca}$ and $\mathrm{CO}_{2}$ release in the rhizosphere by calcite (Figure 6) and probably by the presence of secondary microorganisms in the fungal mantle of ectomycorrhizae [36]. Indeed, it has been demonstrated that the inoculation of jack pine with a combination of Laccaria bicolor and Pseudomonas fluorescens significantly increases seedling growth relative to the effects of either of these treatments (fungus or bacterium) applied alone [37].

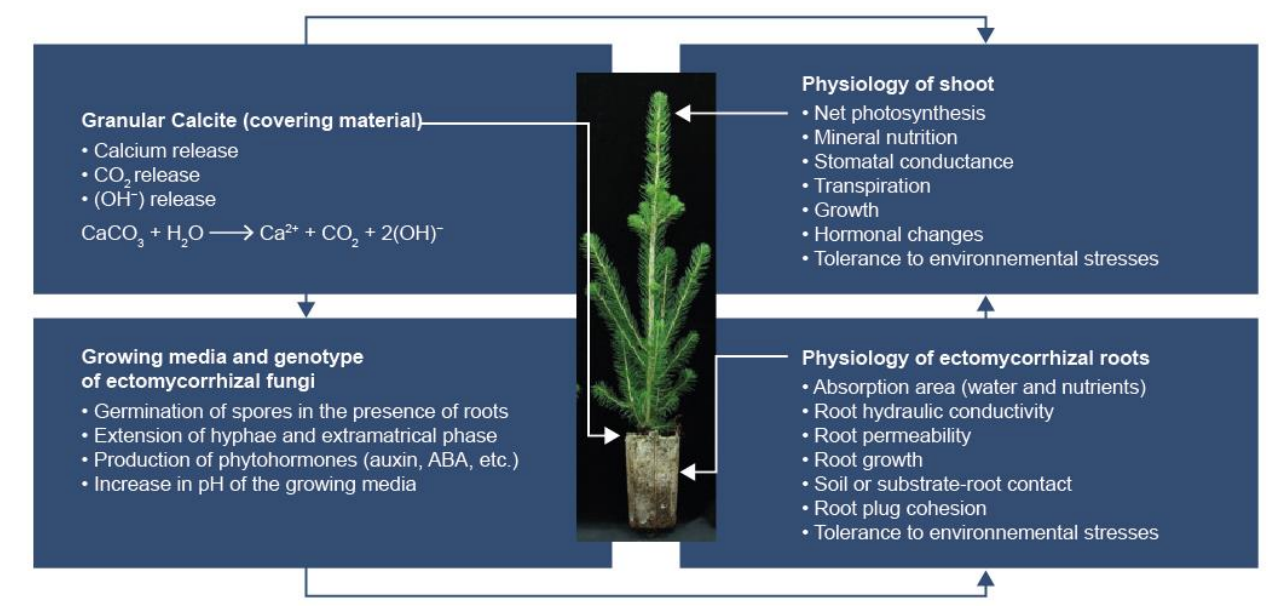

Figure 6. Main mechanisms by which calcite and ectomycorrhizae improve the physicochemistry of the substrate, and the growth and physiology of plants.

Granular calcite $\left(\mathrm{CaCO}_{3}\right)$ used as covering material releases $\mathrm{CO}_{2}$ [38], which is combined with that generated in the rhizosphere by microorganism activity (including ectomycorrhizae) and root respiration $[39,40]$. This additional $\mathrm{CO}_{2}$ stimulates spore germination, and the growth and development of ectomycorrhizal fungal hyphae [41,42], biomass and fruiting bodies [43,44]. After spore germination, the release of $\mathrm{Ca}$ into the rhizosphere by calcite also stimulates the growth and extension of fungal hyphae [45]. This explains why the extramatrical phase of L. bicolor extends and grows rapidly with the increasing gradient of $\mathrm{Ca}$ concentration and $\mathrm{pH}$ (results not shown) from the top of the root plug (where the covering material was present) to the bottom (Figure 3b). It is highly likely that the germination of L. bicolor spores, in the presence of white spruce roots $(2+0)$ [46], requires a minimum concentration of $\mathrm{CO}_{2}$, which is achieved faster in the presence of calcite than silica. Indeed, calcite has the high $\mathrm{CO}_{2}$ emission factor of $44 \%$ [38], while silica does not release $\mathrm{CO}_{2}$. This partly explains the fast growth of L. bicolor's extramatrical hyphae in the presence of calcite. It has been shown that hyphal growth is optimal at a $\mathrm{CO}_{2}$ concentration of $2.5 \%$ for certain endomycorrhizal species (e.g., Gigaspora margarita Becker and Hall) [47].

Root architecture and root plug cohesion of white spruce seedlings were improved following ectomycorrhizal colonization (Figure 3). These observations are consistent with those described by several authors $[22,48,49]$. The anatomical characteristics of ectomycorrhizae and the very high density of extraradical mycelium in the extramatrical phase of L. bicolor significantly increase root length and facilitate the exploration of substrate volume. The extraradical mycelium of L. bicolor is directly connected to seedling roots and represents a functional extension of the root system. For example, the length of the ectomycorrhizal fungus's hyphae under controlled conditions can be $10-80 \mathrm{~m}$ per cm of root [50]. Further work [51,52] has shown that the extension of the extraradical mycelium's surface 
(hyphae and mycelial cords) of Pisolithus sp. Coker and Couch significantly improves root architecture and surface absorption by Pinus pinaster (Aits) seedlings in sandy soil. The measured extension of the extramatrical phase's surface was $1-3 \mathrm{~cm}^{2} /$ day depending on the fungus's genotype.

The extramatrical development of ectomycorrhizal fungi also improves soil and substrate structure, particularly the arrangement and cohesion of aggregates by hyphae and extracellular polysaccharide secretions $[53,54]$. Read $[55]$ estimates that for some ectomycorrhizal fungi, the length of the extramatrical hyphae can reach $200 \mathrm{~m} / \mathrm{g}$ dry soil or $2000 \mathrm{~m} / \mathrm{cm}^{3}$ of fresh soil and that the density of the hyphae in the active area of extension can reach 250 individual filaments per mm linear.

The extramatrical phase of ectomycorrhizal fungi increases the absorption surface of plant roots (water and mineral elements). For white spruce seedlings produced in containers ( $350 \mathrm{~cm}^{3} /$ cavity) in a peat-based substrate, the mean total length of all roots measured by image analysis ( $n=36$ plants) over the entire growing season $(1+0)$ at an operational scale did not exceed $834 \mathrm{~cm}$ under optimal irrigation control $(45 \%, v / v)$, i.e., $0.02 \mathrm{~m} / \mathrm{cm}^{3}$ of fresh substrate [15]. The presence of these fine hyphae, small in diameter relative to the roots, allows the seedlings to explore the full volume of the substrate and to penetrate between the substrate particles where the roots cannot access.

Mycorrhizal colonization also helps reduce the leaching of mineral elements by retaining and immobilizing these elements in its various structures (hyphae, fungal mantle, etc.) [56]. For example, a portion of $\mathrm{Ca}$ is absorbed on the hyphae's surface in the form of calcium oxalate ( $\mathrm{CaOx}$ ) crystals [57]. The formation of $\mathrm{CaOx}$ was significantly increased by the presence of bicarbonates released by calcite and nitrates from fertilization [58]. In this regard, Arocena et al. [59] showed that when Piloderma is associated with the roots of Picea glauca (Moench) Voss x Picea engelmannii Parry, the surface of its hyphae is covered with Ca-rich inlays (e.g., CaOx) with a calcium concentration reaching up to $17 \% \mathrm{Ca}$. These hyphae store significant amounts of mineral elements and help reduce leaching and pollution of the water table. After the hyphae die, Ca is released into the soil solution and absorbed by the roots [57].

Calcite increases $\mathrm{pH}$ to an optimal level $\left(\mathrm{pH}_{\text {water }}=4-5\right)$ for growth and mineral nutrition of boreal forest conifers produced in peat substrates [5], as well as for growth and development of ectomycorrhizal fungi from the boreal forest [25]. Other factors and interactions between $\mathrm{pH}$ and $\mathrm{Ca}$ also contribute to improved substrate physicochemistry, plant growth and physiology (Figure 6).

Our previous results and observations on the main boreal forest species (black spruce, white spruce, jack pine, and larch) produced in Quebec's forest nurseries have shown that root colonization by the extramatrical phase of L. bicolor provides good root plug cohesion and helps reduce insufficient root development $[22,48,49,60]$, which is one of the most important plant rejection criteria [14]. Thus, L. bicolor distinguishes itself by its extremely dense extramatrical phase (Figure 3b), which ensures good cohesion between substrate particles and roots [61]. Improved root plug cohesion by the dense extramatrical phase of L. bicolor has also been reported in white spruce cuttings (B+2) [49]. Maintaining this cohesion is essential for the qualification of nursery seedlings and in the different handling stages between the nursery and the planting site.

\subsection{Calcite: An Asset for the Improvement of Growth and Morphophysiological Quality of Seedlings Produced in Forest Nurseries}

The use of calcite rather than silica as covering material did not affect seed germination or cavity occupancy rate, which averaged $99.33 \%$ for all three treatments.

At the last sampling date of the second growing season, seedlings covered with calcite and calcite+ showed significant height gains over silica-covered seedlings (mean deviation of $21.7 \%$ ), shoot dry mass $(20.6 \%)$, and total mass (18.3\%). Growth model asymptotes (Figure 4) clearly demonstrate the significant superiority of calcite over silica. For dry root mass, the $9 \%$ difference between calcite/calcite+ and silica treatments was not significant, perhaps because root growth was restricted by the cavities $\left(310 \mathrm{~cm}^{3}\right)$ during the second growing season. However, at the end of the first growing season and when cavity volume (root living space) was not a limiting factor, root mass was significantly greater 
with the calcite+ treatment than the silica treatment ( $31 \%$ difference; calcite+: $562.0 \pm 15.0 \mathrm{mg}$; silica: $427.0 \pm 12.0 \mathrm{mg}$; results not shown).

In terms of mineral nutrition, the mean shoot $C$ a content in calcite-covered cavities was significantly higher than that of silica-covered plants (Figure 5). Calcium, alone or through synergy with other factors (ectomycorrhizae, $\mathrm{CO}_{2}$, etc.), significantly increased seedling growth due to its positive effects on different physiological processes. This element activates cell division and elongation, regulates cell membrane permeability, strengthens cell wall rigidity and acts as a regulator of photosynthesis in synergy with abscisic acid during stomatal opening [62-64]. Calcium also stimulates photosynthesis and nitrogen, phosphorus, and potassium absorption $[65,66]$. For other crops (e.g., tobacco), the addition of Ca improves the absorption of trace elements, namely iron, manganese, zinc and boron [67].

In recent years, nursery growers have experienced significant seedling losses due to extreme weather conditions characterized by delayed accumulation of cold hours in autumn and lack of snow cover in early winter [68]. To this end, the use of calcite as covering material along with improved natural seedling ectomycorrhizal inoculation could contribute to improved hardening and frost tolerance of seedlings. Indeed, studies have shown that hardening and frost tolerance are enhanced by calcium supplementation in forest plant nurseries [69] and in fruit and forest trees grown in the field such as apple trees, green oaks and red spruces [70-72]. The presence of ectomycorrhizae in Scots pine (Pinus sylvestris L.) has also been shown to increase hardening and frost tolerance [73,74]. In our view, the combination of calcium and ectomycorrhizal supplementation, the subject of this study, allows the simple effects already observed of these two factors to work in synergy to increase seedling tolerance to other environmental, abiotic (salinity, excess water, drought, high temperatures) [52,66,70,72,75]; and biotic stresses (attacks by pathogens) [76].

In Quebec, artificial inoculation by local L. bicolor spores yielded excellent results at an operational scale in terms of inoculation success and carpophore production. For example, a private nursery inoculated $1+0$ and $2+0$ seedlings of different forest species (jack pine, fir, white, black, red and Norway spruce) in seven tunnels to promote root plug cohesion and improve root growth [22,48]. This inoculation improved root plug cohesion and resulted in an L. bicolor carpophore density of 1-14.5 carpophores $/ \mathrm{m}^{2}$, which represents an average of 61-744 carpophores per tunnel after evaluation of 210 to 600 containers per tunnel. The presence of ectomycorrhizal fungi also improves the plasticity and functional features of planted seedlings, including the acquisition, absorption and transport of water and mineral elements, gas exchanges, and tolerance to different environmental stresses $[40,52,77,78]$.

\section{Conclusions}

To our knowledge, this is the first assessment of the effects of granular calcite used as covering material on substrate physicochemistry, early root colonization by ectomycorrhizal fungi, growth and calcium nutrition of forest seedlings produced at an operational scale.

Calcite significantly improved the physicochemistry of the mycorrhizosphere's substrate, as well as the growth and mineral nutrition of nursery seedlings (Figure 6). The use of granular calcite instead of silica as covering material led to increased mycorrhization and development of the extramatrical phase of ectomycorrhizal fungi as a result of the interaction between three main factors ( $\mathrm{pH}$ improvement, increase in $\mathrm{Ca}$ and $\mathrm{CO}_{2}$ concentrations). Increased root plug cohesion will reduce the number of plants discarded due to insufficient root development $[48,49,60]$. The number of plants discarded for other reasons may also decrease as the calcium released by calcite and ectomycorrhizal colonization increase the seedling's tolerance to abiotic and biotic stresses (frost, pathogenic fungi, etc.).

The use of granular calcite will allow forest nursery workers to reduce fall applications of calcium nitrate $\left(\mathrm{CaNO}_{3}\right)$, which is used as a fertilizer to provide the essential calcium needed for plant hardening and frost tolerance [20]. This decrease will also contribute to reducing nitrate leaching [15] and the cost of fertilizers.

This study led to the development of growth models for $2+0$ white spruce seedlings grown using two types of covering material: silica and granular calcite. These models can be used as nursery stock 
standards by growers looking to optimize their growing techniques and increase the achievement rate of morphophysiological quality standards (during seedling delivery).

Our results on calcite and nursery ectomycorrhizae development, combined with those on the performance of seedlings inoculated with L. bicolor at reforestation sites during the juvenile phase [79-83], can contribute to the achievement of the objectives of the reforestation and assisted migration programs $[79,80]$. More particularly, by improving the survival rate and tolerance of seedlings to different environmental stresses during their establishment phase at reforestation sites.

Finally, calcite can also be used in agriculture, agroforestry and in horticultural nurseries to improve soil physicochemistry and the development of mycorrhizal fungi, as well as to improve yields and resistance to environmental stresses for different crops.

Supplementary Materials: The following are available online at http://www.mdpi.com/2076-2607/8/7/1088/s1, Table S1: Estimation of the parameters of the logistic models of the evolution of the height, the diameter, the dry mass of the shoots, the roots and the total dry mass of the white spruce seedlings $(2+0)$ in a forest nursery. The parameters in bold indicate that the difference between the Silica and (Calcite/calcite) treatments is significant.

Author Contributions: Conceptualization, M.S.L., M.R., J.A.F. and I.A.; methodology, M.S.L., M.R., J.A.F. and I.A.; supervision, M.R. and M.S.L.; project administration, M.R. and M.S.L.; statistical analyses, I.A. and M.S.L.; data curation, M.S.L., M.R., and I.A.; writing—original draft preparation, M.S.L.; writing-review and editing, M.S.L., M.R., J.A.F. and I.A. All authors have read and agreed to the published version of the manuscript.

Funding: Funding for this research project was provided by the Direction de la recherche forestière (DRF) of the Ministry of Forests, Wildlife and Parks of the Government of Quebec as part of project no. 3321142332093: Optimization of the cultural practices affecting root insufficiency and the morphophysiological quality of the seedlings produced in forest nurseries (holder: Mohammed S. Lamhamedi).

Acknowledgments: We sincerely thank Chantal Pelletier, Sylvie Goulet and all the staff of the Grandes-Piles nursery for their exceptional technical assistance during all phases of this project. We thank all the staff of the organic and inorganic chemistry laboratory of the Direction de la recherche forestière (DRF) for the mineral analyses of the samples and the enriching discussions with the chemical managers (Carol DeBlois and Denis Langlois). We thank many reviewers (Daniel Dumais, Steve Bédard, Denise Tousignant, Yves Piché and Jean Gagnon) for their suggestions and comments. We thank the two anonymous reviewers and the staff of the edition for their comments that helped to improve the content of this article.

Conflicts of Interest: The authors declare no conflict of interest. The funders had no role in the design of the study; in the collection, analyses, or interpretation of data; in the writing of the manuscript, or in the decision to publish the results.

\section{References}

1. Caron, J. La tourbe et les milieux artificiels. In Écologie des Tourbières du Québec-Labrador; Payette, S., Rochefort, L., Eds.; Presses de l'Université Laval: Québec, QC, Canada, 2001; pp. 399-410.

2. Heiskanen, J. Favourable water and aeration conditions for growth media used in containerized tree seedling production: A review. Scand. J. For. Res. 1993, 8, 337-358. [CrossRef]

3. Lamhamedi, M.S.; Renaud, M.; Veilleux, L. Les effets de l'augmentation du pH des substrats sur la croissance des plants forestiers produits dans les pépinières forestières. In Proceedings of the Colloque de Tansfert de Connaissances et de Savoir-Faire, Carrefour Forêt Innovations, Québec, QC, Canada, 4-6 October 2011; pp. 33-45.

4. Landis, T.D.; Tinus, R.W.; McDonald, S.E.; Barnett, J.P. The Container Tree Nursery Manual. Vol. 2: Containers and Growing Media; Handbook Agric. no 674, U.S.D.A.; Forest Service: Washington, DC, USA, 1990; 87p.

5. Rikala, R.; Jozefek, H.J. Effect of dolomite lime and wood ash on peat substrate and development of tree seedlings. Silva Fenn. 1990, 24, 323-334. [CrossRef]

6. South, D.B. Optimum pH for growing pine seedlings. Tree Planters' Notes 2017, 60, 49-62.

7. South, D.B.; Nadel, R.L.; Enebak, S.A.; Bickerstaff, G. Sulfur and lime affect soil pH and nutrients in a sandy Pinus taeda nursery. Reforesta 2017, 4, 12-20. [CrossRef]

8. Lamhamedi, M.S.; Renaud, M. Effets de L'ajout de la Chaux Dolomitique sur la Croissance des Plants D'épinette Blanche (2+0) et les Propriétés Physico-Chimiques du Substrat de Croissance; Avis Technique; Gouvernement du Québec, Ministère des Ressources Naturelles et de la Faune, Direction de la Recherche Forestière: Québec, QC, Canada, 2005; 15p. 
9. Rippy, J.F.M. Factors Affecting pH Establishment and Maintenance in Peat Moss-Based Substrates. Ph.D. Thesis, North Carolina State University, Raleigh, NC, USA, 2005; 150p.

10. Boudreault, S.; Pepin, S.; Caron, J.; Lamhamedi, M.S.; Paiement, I. Substrate aeration properties and growth of containerized white spruce: A case study. Vadose Zone J. 2014, 13, 1-15. [CrossRef]

11. Pépin, S.; Boudreault, S.; Paiement, I.; Caron, J.; Lamhamedi, M.S. Les propriétés physiques des substrats affectent-elles la croissance racinaire des plants d'épinette blanche $(2+0)$ en pépinière forestière? In Proceedings of the Colloque de Transfert de Connaissances et de Savoir-Faire, Carrefour Forêt Innovations, Québec, QC, Canada, 4-6 October 2011; pp. 79-85.

12. Lamhamedi, M.S.; Desjardins, P.; Renaud, M.; Veilleux, L. Techniques culturales de production pour améliorer la qualité morpho-physiologique des plants forestiers et la rentabilité des pépinières forestières au Québec. In Journée de Formation et de Transfert de Connaissances, D'expertises et de Savoir-Faire Auprès des Pépinières Forestières du Québec Membres de la Fédération Québécoise des Coopératives Forestières; Gouvernement du Québec, Ministère des Ressources Naturelles, Direction de la Recherche Forestière: Québec, QC, Canada, 2013; pp. 1-130.

13. Lamhamedi, M.S.; Renaud, M.; Desjardins, P.; Veilleux, L. Root growth, plug cohesion, mineral nutrition, and carbohydrate content of $(1+0)$ Picea mariana seedlings in response to a short-day treatment. Tree Planters' Notes 2013, 56, 35-46.

14. Lamhamedi, M.S.; Renaud, M.; Desjardins, P.; Veilleux, L. L'utilisation des toiles claires peut-elle augmenter la croissance des racines des plants d'épinette blanche $(1+0)$ en pépinière forestière? In Proceedings of the Colloque de transfert de connaissances et de savoir-faire, Carrefour Forêt Innovations, Québec, QC, Canada, 4-6 October 2011; pp. 87-95.

15. Lamhamedi, M.S.; Lambany, G.; Margolis, H.A.; Renaud, M.; Veilleux, L.; Bernier, P.Y. Growth, physiology and leachate losses in Picea glauca seedlings $(1+0)$ grown in air-slit containers under different irrigation regimes. Can. J. For. Res. 2001, 31, 1968-1980. [CrossRef]

16. Lamhamedi, M.S.; Labbé, L.; Margolis, H.A.; Stowe, D.C.; Blais, L.; Renaud, M. Spatial variability of substrate water content and growth of white spruce seedlings. Soil Sci. Soc. Am. J. 2006, 70, 108-120. [CrossRef]

17. Stowe, D.C.; Lamhamedi, M.S.; Carles, S.; Fecteau, B.; Margolis, H.A.; Renaud, M.; Bernier, P. Managing irrigation to reduce nutrient leaching in containerized white spruce seedling production. New For. 2010, 40, 185-204. [CrossRef]

18. Gagnon, J.; DeBlois, J. Effects of foliar urea fertilization on nitrogen concentrations of containerized $2+0$ jack pine seedlings produced in forest nurseries. Tree Planters' Notes 2017, 60, 44-50.

19. Girard, D.; Gagnon, J.; Langlois, C.-G. PLANTEC: Un logiciel pour gérer la fertilisation des plants dans les pépinières forestières. Gouvernement du Québec, ministère des Ressources naturelles, Direction de la recherche forestière. Note de Recherche Forestière 2001, 111, 1-8.

20. Landis, T.D.; Tinus, R.W.; McDonald, S.E.; Barnett, J.P. The Container Tree Nursery Manual. Vol. 4: Seedling Nutrition and Irrigation; Handbook Agric. no 674, U.S.D.A.; Forest Service: Washington, DC, USA, 1989; 119p.

21. Gagnon, J. Performance de Plants Mycorhizés après 4 à 21 ans de Croissance dans 15 Plantations établies dans Plusieurs Régions écologiques du Québec; Gouvernement du Québec, Ministère des Forêts, de la Faune et des Parcs, Direction de la Recherche Forestière: Québec, QC, Canada, 2016; Volume 178, pp. 1-31.

22. Gagnon, J.; Lamhamedi, M.S. L'inoculation des plants résineux en récipients par des spores de champignons ectomycorhiziens à l'automne pourrait-elle contribuer à réduire les problèmes d'insuffisance racinaire dans les pépinières forestières du Québec? In Proceedings of the Colloque de Transfert de Connaissances et de Savoir-Faire, Carrefour Forêt Innovations, Québec, QC, Canada, 4-6 October 2011; pp. 27-32.

23. Lamhamedi, M.S.; Abourouh, M.; Fortin, J.A. Technological transfer: The use of ectomycorrhizal fungi in conventional and modern forest tree nurseries in northern Africa. In Advances in Mycorrhizal Science and Technology; Khasa, D., Piché, Y., Coughlan, A.P., Eds.; NRC Research Press: Ottawa, ON, Canada, 2009; pp. 139-152.

24. Marx, D.H.; Ruehle, J.L.; Kenney, D.S.; Cordell, C.E.; Riffle, J.W.; Molina, R.J.; Pawuk, W.H.; Navratil, S.; Tinus, R.W.; Goodwin, O.C. Commercial vegetative inoculum of Pisolithus tinctorius and inoculation techniques for development of ectomycorrhizae on container-grown tree seedlings. For. Sci. 1982, 28 , 373-400. 
25. Dennis, J.J. Effect of $p H$ and Temperature on in Vitro Growth of Ectomycorrhizal Fungi; Information Report BC-X-273; Government of Canada; Canadian Forestry Service; Pacific Forestry Centre: Victoria, BC, Canada, $1985 ; 19 \mathrm{p}$.

26. Choi, D.S.; Jin, H.O.; Chung, D.J.; Sasa, K.; Koike, T. Growth and physiological activity in Larix kaempferi seedlings inoculated with ectomycorrhizae as affected by soil acidification. Trees 2008, 22, 729-735. [CrossRef]

27. Erland, S.; Söderström, B.; Andersson, S. Effects of liming on ectomycorrhizal fungi infecting Pinus sylvestris L. II. Growth rates in pure culture at different $\mathrm{pH}$ values compared to growth rates in symbiosis with the host plant. New Phytol. 1990, 115, 683-688. [CrossRef]

28. Gagnon, J.; Langlois, C.-G.; Fortin, J.A. Growth of containerized jack pine seedlings inoculated with different ectomycorrhizal fungi under a controlled fertilization schedule. Can. J. For. Res. 1987, 17, 840-845. [CrossRef]

29. Gagnon, J.; Langlois, C.-G.; Fortin, J.A. Growth and ectomycorrhiza formation of containerized black spruce seedlings as affected by nitrogen fertilization, inoculum type, and symbiont. Can. J. For. Res. 1988, 18, 922-929. [CrossRef]

30. Lamhamedi, M.S.; Renaud, M. Les ectomycorhizes dans les pépinières forestières au Québec: Éléments historiques et effets sur la qualité morpho-physiologique des plants. In Proceedings of the Conférence Présentée au Colloque: Mycorhizes, Québec, QC, Canada, 10-11 May 2017.

31. Lehto, T.; Zwiazek, J.J. Ectomycorrhizas and water relations of trees: A review. Mycorrhiza 2011, 21, 71-90. [CrossRef]

32. Lamhamedi, M.S. Variabilité de la Qualité de la Silice et Comparaison des Effets de la Silice et de la Calcite sur la Croissance et la Nutrition Minérale des Plants en Pépinière Forestière. Journée de Transfert de Connaissances; Office des Producteurs de Plants Forestiers du Québec: Québec, QC, Canada, 2015; 66p.

33. Fournier, J.; Bonnot-Courtois, C.; Paris, R.; Vot, M.L. Analyses Granulométriques, Principes et Méthodes; CNRS: Dinard, France, 2012; 100p.

34. Kalra, Y.P.; Maynard, D.G. Méthodes D'analyses des Sols Forestiers et des Tissus Végétaux; Rapport d'information NOR-X-319F; Forêts Canada, Région du Nord-Ouest; Centre de Foresterie du Nord: Edmonton, AB, Canada, $1992 ; 129 \mathrm{p}$.

35. Timmer, V.R.; Armstrong, G.; Miller, B.D. Steady-state nutrient preconditioning and early outplanting performance of containerized black spruce seedlings. Can. J. For. Res. 1991, 21, 585-594. [CrossRef]

36. Garbaye, J.; Bowen, G.D. Stimulation of ectomycorrhizal infection of Pinus radiata by some microorganisms associated with the mantle of ectomycorrhizas. New Phytol. 1989, 112, 383-388. [CrossRef]

37. Gagnon, J. Stimulation of mycorrhization and growth for containerized jack pine seedlings inoculated with Laccaria bicolor and Pseudomonas fluorescens. In Mycorrhizas in Integrated Systems from Genes to Plant Development, Proceedings of the fourth European Symposium on Mycorrhizas, Granada, Spain, 11-14 July 1994; Azcon-Aguilar, C., Barea, J.M., Eds.; Commission Européenne: Luxembourg, 1996; pp. 634-637.

38. De Klein, C.; Novoa, R.S.A.; Ogle, S.; Smith, K.A.; Rochette, P.; Wirth, T.C. Émissions de N2O des sols gérés et émissions de CO2 dues au chaulage et à l'applicationd'urée. In Lignes Directrices 2006 du GIEC Pour les Inventaires Nationaux de Gaz à Effet de Serre; Agriculture, Foresterie et Autres Affectations des Terres: Hayama, Japan, 2006; Volume 4, pp. 1-60.

39. Bekele, A.; Kellman, L.; Beltrami, H. Soil profile $\mathrm{CO}_{2}$ concentrations in forested and clear cut sites in Nova Scotia, Canada. For. Ecol. Manag. 2007, 242, 587-597. [CrossRef]

40. Leake, J.; Johnson, D.; Donnelly, D.; Muckle, G.; Boddy, L.; Read, D. Networks of power and influence: The role of mycorrhizal mycelium in controlling plant communities and agroecosystem functioning. Can. J. Bot. 2004, 82, 1016-1045. [CrossRef]

41. Bécard, G.; Piché, Y. Fungal growth stimulation by $\mathrm{CO}_{2}$ and root exudates in vesicular-arbuscular mycorrhizal symbiosis. Appl. Environ. Microbiol. 1989, 55, 2320-2325. [CrossRef] [PubMed]

42. Tabak, H.H.; Cooke, W.B. The effects of gaseous environments on the growth and metabolism of fungi. Bot. Rev. 1968, 34, 126-252. [CrossRef]

43. Andrew, C.; Lilleskov, E.A. Productivity and community structure of ectomycorrhizal fungal sporocarps under increased atmospheric $\mathrm{CO}_{2}$ and $\mathrm{O}_{3}$. Ecol. Lett. 2009, 12, 813-822. [CrossRef] [PubMed]

44. Pickles, B.J.; Egger, K.N.; Massicotte, H.B.; Green, D.S. Ectomycorrhizas and climate change. Fungal Ecol. 2012, 5, 73-84. [CrossRef]

45. Jackson, S.L.; Heath, I.B. Roles of calcium ions in hyphal tip growth. Microbiol. Rev. 1993, 57, 367-382. [CrossRef] 
46. Kope, H.H.; Fortin, J.A. Germination and comparative morphology of basidiospores of Pisolithus arhizus. Mycologia 1990, 82, 350-357. [CrossRef]

47. Poulin, M.J.; Bel-Rhlid, R.; Piché, Y.; Chênevert, R. Falvonoids released by carrot (Daucus carota) seedlings stimulate hyphal growth of vesicular-arbuscular mycorrhizal fungi in the presence of optimal $\mathrm{CO}_{2}$ enrichment. J. Chem. Ecol. 1993, 19, 2317-2327. [CrossRef]

48. Lamhamedi, M.S. Principaux facteurs influençant le développement racinaire et effets de l'irrigation sur la croissance et la physiologie des racines en pépinière forestière. In Recueil des Conférences et des Résumés du $4 e$ Atelier sur la Production de Plants Forestiers du Québec; Gouvernement du Québec, Ministère des Ressources Naturelles et de la Faune [cd-rom]: Sainte-Foy, QC, Canada, 2006; p. 2p.

49. Lamhamedi, M.S. La masse des racines pourrait-elle être utilisée comme un critère de qualité avant la livraison des plants en site de reboisement? In Proceedings of the Colloque de Transfert de Connaissances et de Savoir-Faire, Carrefour Forêt Innovations, Québec, QC, Canada, 4-6 October 2011; pp. 65-69.

50. Read, D.J.; Boyd, R. Water relations of mycorrhizal fungi and their host plants. In Water, Fungi and Plants; Ayres, P.G., Body, L., Eds.; Cambridge University Press: Cambridge, UK, 1986; pp. 287-304.

51. Lamhamedi, M.S.; Fortin, J.A.; Kope, H.H.; Kropp, B.R. Genetic variation in ectomycorrhiza formation by Pisolithus arhizus on Pinus pinaster and Pinus banksiana. New Phytol. 1990, 115, 689-697. [CrossRef]

52. Lamhamedi, M.S.; Bernier, P.Y.; Fortin, J.A. Hydraulic conductance and soil water potential at the soil-root interface of Pinus pinaster seedlings inoculated with different dikaryons of Pisolithus sp. Tree Physiol. 1992, 10, 231-244. [CrossRef]

53. Perry, D.A.; Molina, R.; Amaranthus, M.P. Mycorrhizae, mycorrhizospheres, and reforestation: Current knowledge and research needs. Can. J. For. Res. 1987, 17, 929-940. [CrossRef]

54. Rillig, M.C.; Mummey, D.L. Mycorrhizas and soil structure. New Phytol. 2006, 171, 41-53. [CrossRef]

55. Read, D.J. The mycorrhizal mycelium. In Mycorrhizal Functioning: An Integrative Plant-Fungal Process; Allen, M., Ed.; Chapman and Hell: New York, NY, USA, 1992; pp. 102-133.

56. Näsholm, T.; Högberg, P.; Franklin, O.; Metcalfe, D.; Keel, S.G.; Campbell, C.; Hurry, V.; Linder, S.; Högberg, M.N. Are ectomycorrhizal fungi alleviating or aggravating nitrogen limitation of tree growth in boreal forests? New Phytol. 2013, 198, 214-221. [CrossRef] [PubMed]

57. Monfort-Salvador, I.; Garcia-Montero, L.G.; Grande, M.A. Impact of calcium associated to calcareous amendments on ectomycorrhizae in forests: A review. J. Soil Sci. Plant Nut. 2015, 15, 217-231. [CrossRef]

58. Lapeyrie, F.; Chilvers, G.A.; Bhem, C.A. Oxalic acid synthesis by the mycorrhizal fungus Paxillus involutus (Batsch. Ex Fr.) Fr. New Phytol. 1987, 106, 139-146. [CrossRef]

59. Arocena, J.M.; Glowa, K.R.; Massicotte, H.B. Calcium-rich hypha encrustations on Piloderma. Mycorrhiza 2001, 10, 209-215. [CrossRef]

60. Lamhamedi, M.S.; Renaud, M.; Desjardins, P.; Veilleux, L. Évaluation de la qualité morpho-physiologique du système racinaire des plants du mélèze laricin: Les racines foncées ou noires peuvent-elles être considérées mortes? Avis. Tech. SGRE 2011, 3, 1-33.

61. Allen, M.F. Mycorrhizal fungi: Highways for water and nutrients in arid soils. Vadose Zone J. 2007, 6, $291-297$. [CrossRef]

62. White, P.J.; Broadley, M.R. Calcium in plants. Ann. Bot. 2003, 92, 487-511. [CrossRef]

63. Hochmal, A.K.; Shulze, S.; Trompelt, K.; Hippler, M. Calcium-dependent regulation of photosynthesis. Biochim. Biophys. Acta 2015, 1847, 993-1003. [CrossRef]

64. Desilva, D.L.R.; Hetherington, A.M.; Mansfield, T.A. Synergism between calcium ions and abscisic acid in preventing stomatal opening. New Phytol. 1985, 100, 473-482.

65. Feagley, S.E.; Fenn, L.B. Using Soluble Calcium to Stimulate Plant Growth; Publication no L-5212, Texas Agricultural Extension Service; The Texas A\&M University System: College Station TX, USA, 1998; 4p.

66. Yang, B.Z.; Liu, Z.B.; Zhou, S.D.; Ou, L.J.; Dai, X.Z.; Ma, Y.Q.; Zhang, Z.Q.; Chen, W.C.; Li, X.F.; Liang, C.L.; et al. Exogenous $\mathrm{Ca}^{2+}$ alleviates waterlogging-caused damages to pepper. Photosynthetica 2016, 54, 620-629. [CrossRef]

67. Lopez-Lefebre, L.R.; Rivero, R.M.; García, P.C.; Sanchez, E.; Ruiz, J.M.; Romero, L. Effect of calcium on mineral nutrient uptake and growth of tobacco. J. Sci. Food Agric. 2001, 81, 1334-1338. [CrossRef]

68. Lamhamedi, M.S.; Veilleux, L.; Renaud, M.; Desjardins, P. Prédiction et détermination des seuils de tolérance au gel en automne et techniques de protection contre le gel hivernal. In Proceedings of the Colloque de Transfert de Connaissances et de Savoir-Faire, Carrefour Forêt Innovations, Québec, QC, Canada, 4-6 October 2011; pp. 53-64. 
69. Landis, T.D. Secondary nutrients-Calcium. For. Nurs. Notes 1996, 8, 8-11.

70. Palta, J.P. Role of calcium in plant responses to stresses: Linking basic research to the solution of practical problems. HortScience 1996, 31, 51-57. [CrossRef]

71. Halman, J.M.; Schaberg, P.G.; Hawley, G.J.; Eagar, C. Calcium addition at the Hubbard Brook Experimental Forest increases sugar storage, antioxidant activity and cold tolerance in native spruce (Picea rubens). Tree Physiol. 2008, 28, 855-862. [CrossRef]

72. Percival, G.; Barnes, S. Calcium-induced freezing and salinity tolerance in evergreen oak and apple cv. Golden Crown'. Arbor. Urban For. 2008, 34, 191-199.

73. Korhonen, A.; Lehto, T.; Repo, T. Frost hardiness of mycorrhizal and non-mycorrhizal Scots pine under two fertilization treatments. Mycorrhiza 2015, 25, 377-386. [CrossRef]

74. Otgonsuren, B.; Lee, M.J. Ectomycorrhiza enhanced the cold-acclimation growth and freeze tolerance of Scots pine (Pinus sylvestris L.). Taiwan J. For. Sci. 2013, 28, 97-111.

75. Zhao, H.J.; Tan, J.-F. Role of calcium ion in protection against heat and high irradiance stress-induced oxidative damage to photosynthesis of wheat leaves. Photosynthetica 2005, 43, 473-476. [CrossRef]

76. Whipps, J.M. Prospects and limitations for mycorrhizas in biocontrol of root pathogens. Can. J. Bot. 2004, 82, 1198-1227. [CrossRef]

77. Grossnickle, S.C. Ecophysiology of Northern Spruce Species. The Performance of Planted Seedlings; NRC Research Press: Ottawa, ON, Canada, 2000; 407p.

78. Read, D.J.; Leake, J.R.; Perez-Morenco, J. Mycorrhizal fungi as drivers of ecosystem processes in heathland and boreal forest biomes. Can. J. Bot. 2004, 82, 1243-1263. [CrossRef]

79. Benomar, L.; Lamhamedi, M.S.; Pépin, S.; Rainville, A.; Lambert, M.-C.; Margolis, H.A.; Bousquet, J.; Beaulieu, J. Thermal acclimation of photosynthesis and respiration of southern and northern white spruce seed sources tested along a regional climatic gradient indicates limited potential to cope with temperature warming. Ann. Bot. 2018, 121, 443-457. [CrossRef]

80. Lamhamedi, M.S.; Rainville, A.; Benomar, L.; Villeneuve, I.; Beaulieu, J.; Bousquet, J.; Margolis, H.A.; DeBlois, J.; Lambert, M.-C. L'écophysiologie, un atout pour réussir la migration assistée de sources génétiques d'épinette blanche. Gouvernement du Québec, ministère des Forêts, de la Faune et des Parcs. Avis de Recherche Forestière 2017, 89, 1-2.

81. McAffee, B.; Fortin, J.A. The influence of $\mathrm{pH}$ on the competitive interactions of ectomycorrhizal mycobionts under field conditions. Can. J. For. Res. 1987, 17, 859-864. [CrossRef]

82. McAffee, B.; Fortin, J.A. Competitive interactions of ectomycorrhizal mycobionts under field conditions. Can. J. Bot. 1986, 64, 848-852. [CrossRef]

83. McAffee, B.; Fortin, J.A. Ectomycorrhizal colonization on black spruce and jack pine seedlings outplanted in reforestation sites. Plant Soil. 1989, 116, 9-17. [CrossRef]

(C) 2020 by the authors. Licensee MDPI, Basel, Switzerland. This article is an open access article distributed under the terms and conditions of the Creative Commons Attribution (CC BY) license (http://creativecommons.org/licenses/by/4.0/). 